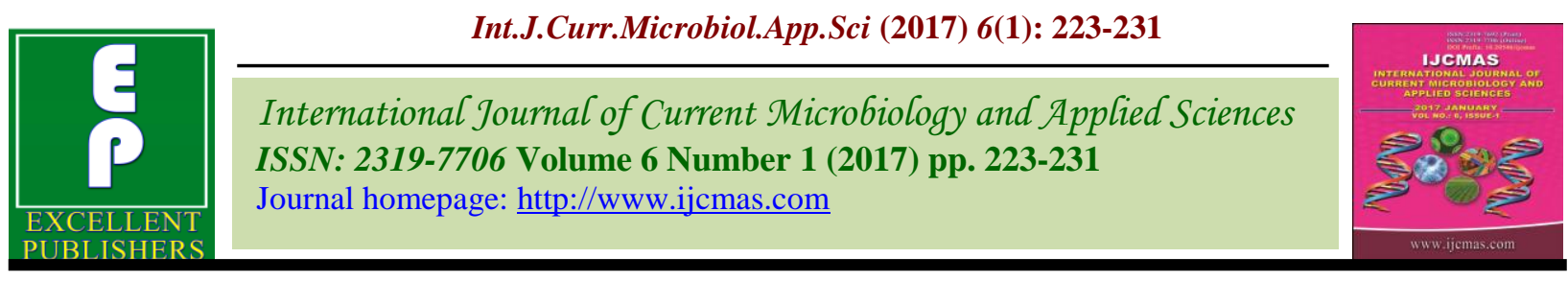

Original Research Article

http://dx.doi.org/10.20546/ijcmas.2017.601.027

\title{
The Biological Control Bacteria Pseudomonas fluorescens Inhibits Free Nitrogen Fixing Bacteria in the Rhizosphere
}

\author{
Abo-baker Abd-Elmoniem Abo-baker Basha ${ }^{1} *$ and Rafat Khalaphallah ${ }^{2}$ \\ ${ }^{1}$ Soils and Water Science, Dept., Fac. Agric., South Valley University, Egypt \\ ${ }^{2}$ Agriculture botany (Microbiology) Dept., Fac. Agric., South Valley University, Egypt \\ *Corresponding author:
}

\section{A B S T R A C T}

Keywords

N2 fixation,

A.chroococcum,

A. lipoferum,

P. fluorescens,

ineraction,

antagonistic effect.

Article Info

Accepted:

12 December 2016

Available Online:

10 January 2017
The present study was conducted in the laboratory and green house to explore the relation between Pseudomonas fluorescens as biocontrol agent and free N-fixers Azotobacter chroococcum and Azospirillum lipoferium bacteria and their effect on their population in rhizosphere, growth, $\mathrm{N} \%$ in shoot and $\mathrm{N}$ content of wheat plants grown in sterilized and unsterilized sandy soil. Results revealed that $P$. fluorescens interacted negatively with the population of both nitrogen fixing bacteria in wheat rhizosphere and studied plant parameters. Results showed that decreased in A. chroococccum counts in wheat rhizosphere of sterilized soil reached to $93.79 \%$ compared to A. chroococccum count in single, while decrease was reached to $82.1 \%$ in unsterilized soil. Also, data obtained showed that in sterilized soil; mixing of $P$. fluoresences with A. lipoferum caused highly significant lowering in population of A. lipoferum reached to $97.87 \%$, and by $91.53 \%$ in unsterilized soil comparing with A. lipoferum inoculated singly. According to these results, it is necessary to separate these non-compatible types of bacteria, when added to the soil or seeds to avoid this antagonistic effect between biocontrol bacteria and introduced or indigenous microorganisms and select the compatible organisms in mixed biofertilizer inoculants.

\section{Introduction}

Microbial interactions in the rhizosphere are one of the main importance for plant growth and health Raaijmakers et al., (2009). Extensive studies were done for the beneficial effect of fluorescent Pseudomonas as plant growth promotion or biological control bacteria (Couillerot et al., 2009). Plant beneficial effects by fluorescent pseudomonads include the inhibition of soil pathogen fungi involving production of siderophores (Lemanceau et al., 1992) and antibiotic like substances secondary metabolites (Raaijmakers et al., 2002).
Nowadays, many commercial products for plant disease control are based on single bacteria strain like Pseudomonas fluorescens formulated to be used as biological control agents.

The use Pseudomonas fluorescens as PGPR and/or biological control agents requires the detailed understanding of its interactions with other bacteria and their performance in soil environment Gotz et. al., (2006). There are a few researches on the relation and interaction between microorganisms used as 
inoculants. So, the aim of this study was to assess the interaction impact of Pseudomonas fluorescens bacteria when mixed with other rhizobacteria such as A.chroococcum and A. lipoferum, two of the most important species of plant-growthpromoting rhizobacteria and its effect on their rhizosphere population, growth, N\% and content of wheat plants grown in sterilized and unsterilized sandy soil. Thus, selecting bacterial strain for production multiple inoculants and better understand of their interaction is an important consideration to produce efficient inoculum which promoting plant growth and/or suppressing diseases.

\section{Materials and Methods}

\section{Microbial cultures used in the study}

All strains of Azotobacter chroococcum, Azospirillum lipoferum, and Pseudomonas fluorescens, were locally isolated in previous study by (Abo-Baker, 2003). Fusarium sp pathogen fungi was supplied by Agriculture botany (microbiology) Dept., Fac. Agric., South Valley Univ., Egypt.

Test of antagonistic ability of $P$. fluorescens against Fusarium sp on plate agar media. (in vitro)

Dual culture technique (Dennis and Webster, 1971) was employed to prove (in vitro) the antagonistic ability of Pseudomonas fluorescens against the pathogenic fungi Fusarium sp. on potato dextrose agar (PDA) plates, (Beever and Bollard, 1970).

Study the interaction between nitrogen fixers and biological control of $P$. fluorescences in the rhizosphere of wheat plants (Pots experiments).

Pots (15 cm diameter) experiments were conducted using sterilized and unsterilized sandy soil to evaluate the interaction effect between nitrogen fixers (A. chroococcum and A. lipoferum) and biological control Pseudomonas fluorescencs on their population in wheat rhizosphere and determine the nitrogen fixing capacity by $A$. chroococcum and $A$. lipoferum as indicated by $\mathrm{N} \%$ and $\mathrm{N}$-content of wheat plants. The experimental soil has Sandy texture, $\mathrm{pH}$ 8.3, $3.25 \mathrm{CaCO}_{3} \%, 1.95 \mathrm{dsm}^{1} \mathrm{EC}, 0.011$ Total $\mathrm{N} \%$ and $20.6 \%$ water saturation capacity. Four grains of wheat (Triticum aestivum L. cv. Geza 168) / pot were planted and inoculated by adding $1 \mathrm{ml} /$ grain of 6,7 and 4 days old liquid culture of A.lipoferum, $A$. chroococcum and $P$. fluorescens contain $3 \times 10^{6} \mathrm{CFU} \mathrm{mL}^{-1}, 5.4 \times 10^{5} \mathrm{CFU} \mathrm{mL}^{-1}$ and 6.5 $\mathrm{x} 10^{7} \mathrm{CFU} \mathrm{mL}^{-1}$ respectively, the grains inoculated singly or in dual inoculation under sterilized and unsterilized soil.

\section{Enumeration of selected microbial population in wheat rhizosphere}

The soil samples were taken from rhizospheric zone of different treatments for enumerating the targeted microorganisms in soil using serial dilution method. For pseudomonas count, the poured plate count method was used, $1 \mathrm{ml}$ of the appropriate dilution was transferred to King's B. medium (King et al., 1954) agar plates which were incubated at $28^{\circ} \mathrm{C}$ for 3 days. Pseudomonas counts were recorded when particular colonies developed. The most probable number (MPN) method of (Alexander, 1965) was used for estimation of Azotobacter and Azospirillum population in wheat rhizosphere using Ashby's modified medium for Azotobacter (AbdelMalek and Ishac, 1968) and semi-solid Nitrogen Free Bromothymol Blue (NFB) medium (Dobereiner et al., 1976) for Azospirillum. The MPN tubes were incubated at $28 \pm 2^{\circ} \mathrm{C}$ for Azotobacter and $35^{\circ} \mathrm{C}$ for Azospirillum. Microbial counts 
were recorded when particular growth developed in tubes. The results were expressed as CFU $\mathrm{g}^{-1}$ dry soil.

\section{Statistical analysis}

All data obtained were analyzed using MSTAT- C (Russell, 1994) and one way analysis of variance was applied. The differences between means of the different treatments were compared using the least significant difference (L.S.D.) at $5 \%$ and $1 \%$ probability.

\section{Results and Discussion}

Antagonistic ability of $P$. fluorescens against Fusarium sp. on plate agar media (in vitro)

It is evident from Photo 1 that growth of the pathogenic fungi Fusarium $s p$ was inhibited by $P$. fluorescens in vitro as indicated by the limited growth of fungi between $P$. fluorescens streaks comparing with the growth in control plate inoculated with fungi only. This can explained on the basis of the inhibitory effects of $P$. fluorescens on Fusarium pathogen fungi. In this respect Keel et al., (1990) and Thomashow and Weller (1995) reported that this inhibitory effect due to ability of Pseudomonas fluorescens to produce several metabolites with antibiotic or toxic activity which suppresses several pathogenic fungi.

Also, Nicodème et al., (2005) found that hydrogen cyanides, siderophores, and antibiotics was a metabolites produced by Pseudomonas fluorescens and consider the primary mechanism of biocontrol.

Interaction between nitrogen fixers and biological control agent $P$. fluorescences in the rhizosphere of wheat (Pot experiment)

The rhizosphere population of $A$. chroococcum single inoculation $\left(0.145 \times 10^{3}\right.$ $\left.\mathrm{CFU} \mathrm{\textrm {g } ^ { - 1 }}\right)$, A. lipoferum $\left(4.032 \times 10^{3} \mathrm{CFU} \mathrm{g}^{-1}\right)$ and $P$. fluorescens $\left(624.5 \times 10^{3} \mathrm{CFU} \mathrm{\textrm {g } ^ { - 1 }}\right)$ were significantly higher compared to uninoculated control in sterilized soil, while the counts in unsterilized soil reached to $\left(0.134 \times 10^{3} \mathrm{CFU} \mathrm{g}^{-1}\right),\left(1.5 \times 10^{3} \mathrm{CFU} \mathrm{g}^{-1}\right)$ and (292.6 $\times 10^{3} \mathrm{CFU} \mathrm{g}^{-1}$ ), for A. chroococcum, A. lipoferum and P. fluorescens, respectively (Table 1).

A. chroococcum population in wheat rhizosphere as affected by mixing with $\boldsymbol{P}$. fluorescens

Data of A. chroococcum count showed that under sterilized soil, mixing of $P$. fluoresences with $A$. chrooccum caused highly significant reduction in $A$. chroococcum population from $0.145 \times 10^{3}$ $\mathrm{CFU} \mathrm{g} \mathrm{g}^{-1}$ to $0.009 \times 10^{3} \mathrm{CFU} \mathrm{g}^{-1}$ after 30 days; which reached to $93.79 \%$ comparing to A. chroococccum count individually inoculated (Table 1).

Also, data in (Table 1) showed that under unsterilized soil, highly significant reduction in A. chroococcum counts was happened when mixed with Pseudomonas fluoresce in wheat soil rhizosphere. This decrease was reached to $82.1 \%$ comparing with single $A$. chrooccum treatments.

On the other hand, the decline in the number of A. chroococcum when mixed with Pseudomonas fluoresce was pronounced in sterilized soil compared to unsterilized one. In accordance with our results, Zehra et al., (2015) found that the efficiency of the biofertilizers was higher in case of application single beneficial microorganisms. They added that this might be due to the incompatibility of the rhizobacterial strains used as biofertilizers or due to antagonistic effect and secretion of some toxic substances by the bacteria. 
A. lipoferum population in wheat rhizosphere as affected by mixing with $\boldsymbol{P}$. fluorescens

Data in Table 1 showed that A. lipoferum population of wheat rhizosphere in sterilized and unsterilized soil influenced highly significant by mixing with P.fluoresences. Results showed that in sterilized soil; mixing $P$. fluoresences with $A$. lipoferum caused highly significant lowering in population of A. lipoferum reached to $97.87 \%$, comparing with A. lipoferum inoculation singly. Also, similar result was found in unsterilized soil where the numbers of $A$. lipoferum decreased by $91.53 \%$ comparing with $A$. lipoferum singly inoculated. Olivier et al., (2011) found that Pseudomonas fluorescens produce antimicrobial metabolite 2,4diacetylphloroglucinol production resulted in lower Azospirillum cell numbers per root system (based on colony counts) and restricted microscale root colonization of neighboring Azospirillum cells (based on confocal microscopy). They added; regardless of the $A$. brasilense strain used pseudomonads have the potential to interfere with $A$. brasilense phytostimulators on roots and with their plant growth promotion capacity.

Pseudomonas fluorescens population in rhizosphere as affected by both of $A$. chroococcum and $A$. lipoferum inoculation

Regarding the effect of both $A$. chroococcum and A. lipoferum on P.fluoresences count in rhizosphere of wheat, results showed significant decrease in the number of $P$. fluoresences when mixed with $A$. chroococcum and A. lipoferum reached to $22.34 \%$ and $28.6 \%$, respectively under sterilized soil conditions, (Table 1). Furthermore, the decrease in the number of $P$. fluoresences under unsterilized soil was higher than in sterilized soil which reached to $68.73 \%$ and $82,94 \%$ when mixed with $A$. chrooccum and A. lipoferum, respectively comparing with $P$. fluoresences single treatment solely, (Table1).

Results of Berendsen et al., (2012) revealed that, bacteria in rhizosphere may have direct beneficial or harmful effect to other soil bacteria or other microorganisms. Also, plant growth promotion rhizobacteria have developed mechanisms to affect and respond to each other. Combes-Meynet et al., 2011 found that production the 2,4diacetylphloroglucinol (2,4-DAPG secondary metabolites from $P$. fluorescens may affect other PGPR like Azospirillum. The decrease in the number of $P$. fluoresences under both sterilized and unsterilized soils may be due to that $P$. fluoresences have low competence ability with other indigenous and introduce rhizosphere bacteria in unsterilized soil. inoculation with $P$. fluorescens alone was more effective than inoculations in which $P$. fluorescens was combined with other plant growth promotion rhizobacteria Anwar-ulHaq et al., ( 2011). Competition for nutrients like organic acids, cell motility, space with other rhizobacteria is a factor that will negatively affect $P$. fluorescens population Prieto et al., (2011).

Plant dry weight (g/plant), $\mathrm{N} \%$ and $\mathrm{N}$ content (mg/plant) of wheat as affected by single and mixed inoculation

Results of wheat dry weight, $\mathrm{N} \%$ and $\mathrm{N}$ content showed that control treatment recorded the lowest values in selected wheat parameters whereas the wheat dry weight, $\mathrm{N} \%$ and $\mathrm{N}$-content in control treatment were higher in case of unsterilized soil than in sterilized for all treatments. This may be due to the activity of indigenous microorganisms in unsterilized soil to promote wheat plants growth. Also, results showed that all single inoculation treatments with the individually selected strains except $P$. fluorescens scored 
highly significant increases in shoot dry weight, $\mathrm{N} \%$ and $\mathrm{N}$-content of wheat plants. The promotive treatments were those singly inoculated with selected $A$. lipoferum and $A$. chroococcum strains either in sterilized or unsterilized soil but the values were higher significantly in most parameters in sterilized soil than in unsterilized.

These results indicated that the promotive effects induced by the inoculated rhizobacterial strains is due to supplying plants with excess amount of fixed nitrogen, similar positive effects of wheat seed inoculation with Azotobacter were reported on tomato (Imam et al., 1977).

Also, In addition, results showed that inoculation with $P$. fluorescens, either individually or co-inoculated in mixed culture with any of the tested strains did not generate significant improvement in shoot dry weight, $\mathrm{N} \%$ and N-content. $P$. fluorescens strains are usually used in plant inoculation for biocontrol of pathogenic fungi diseases (Parke, 1990) and the promotive effects produced are mainly due to their antagonistic effects on the other deleterious microbes (Sorensen et al., 2001).

Inoculation of wheat grains with $P$. fluorescens in mixture with either $A$. chroococcum or with $A$. lipoferum significantly reduced wheat shoot dry weight, $\mathrm{N} \%$ and nitrogen content comparing with $A$. chroococcum and A. lipoferum in single inoculation treatments. This significant reduction can be attributed to the inhibitory interaction between P. fluorescens and rhizobacterial inoculants (Abo-Baker, 2011). Moreover, the results showed that mixing $P$. fluorescens with $A$. chroococcum led to highly significant decrease in dry weight, $\mathrm{N} \%$ and $\mathrm{N}$ - content of wheat plant comparing to $A$. chroococcum solely inoculated, the reduction in parameters values in unsterilized soil reached to $36.53 \%, 29.29 \%$ and $54.97 \%$ for shoot dry weight, $\mathrm{N} \%$ and nitrogen content respectively, and $58.02 \%, 48.68 \%$ and 78.38 $\%$ in sterilized soil for the previous parameters, respectively.

Table.1 Effect of the interaction between biological control P. fluorescens on both of

A. lipoferum and A. chroococcum population in wheat rhizosphere under sterilized and unsterilized soil

\begin{tabular}{|c|c|c|c|c|}
\hline \multirow[b]{2}{*}{ Inoculation Treatments } & \multicolumn{2}{|c|}{ A. chroococcum Counts X $10^{3}$} & \multicolumn{2}{|c|}{ P. fluorescens Counts $\mathrm{X} 10^{3}$} \\
\hline & Unsterilized soil & Sterilized soil & $\begin{array}{l}\text { Unsterilized } \\
\text { soil }\end{array}$ & Sterilized soil \\
\hline Uninoculated (control) & $0.002 \pm 0.00$ & $0.000 \pm 0.00$ & $0.170 \pm 0.02$ & $0.000 \pm 0.00$ \\
\hline A. chroococcum single $(\mathrm{S})$ & $0.134 \pm 0.01$ & $0.145 \pm 0.01$ & $292.559 \pm 29.6$ & $624.483 \pm 62.45$ \\
\hline A. chroococcum+ P. fluorescens (Mixed) & $0.024 \pm 0.002$ & $0.009 \pm 0.0006$ & $91.455 \pm 9.15$ & $484.958 \pm 48.5$ \\
\hline LSD 0.05 & \multicolumn{2}{|l|}{0.016} & \multicolumn{2}{|l|}{61.59} \\
\hline \multirow[t]{3}{*}{ LSD 0.01} & \multicolumn{2}{|l|}{0.023} & \multicolumn{2}{|l|}{86.34} \\
\hline & \multicolumn{2}{|c|}{ A. lipoferum Counts $\times$ X $10^{3}$} & \multicolumn{2}{|c|}{ P. fluorescens Counts $\mathrm{X} 10^{3}$} \\
\hline & Unsterilized soil & Sterilized soil & $\begin{array}{l}\text { Unsterilized } \\
\text { soil }\end{array}$ & Sterilized soil \\
\hline Uninoculated (control) & $0.029 \pm 0.003$ & $0.000 \pm 0.00$ & $0.170 \pm 0.02$ & $0.000 \pm 0.00$ \\
\hline A. lipoferum single $(\mathrm{S})$ & $1.500 \pm 0.15$ & $4.032 \pm 0.40$ & $292.559 \pm 29.6$ & $624.5 \pm 62.45$ \\
\hline A. lipoferum $+P$. fluorescens (Mixed) & $0.127 \pm 0.01$ & $0.086 \pm 0.01$ & $49.889 \pm 4.94$ & $445.863 \pm 44.59$ \\
\hline LSD 0.05 & \multicolumn{2}{|l|}{0.3132} & \multicolumn{2}{|l|}{59.57} \\
\hline LSD 0.01 & \multicolumn{2}{|l|}{0.4391} & \multicolumn{2}{|l|}{83.76} \\
\hline
\end{tabular}

[Values are the mean of 4 replicates] \pm shows standard deviation. 
Table. 2 Wheat dry weight, $\mathrm{N} \%$ and N-content of wheat as affected by single and mixed inoculation with $A$. chroococcum and $P$. fluorescens

\begin{tabular}{|l|l|l|l|}
\hline Inoculation Treatments & $\begin{array}{l}\text { Dry weight } \\
(\mathrm{g} / \text { plant })\end{array}$ & $\begin{array}{l}\text { Shoot } \\
(\mathrm{N} \%)\end{array}$ & N-content(mg/plant) \\
\hline Sterilized soil & $0.290 \pm 0.03$ & $0.052 \pm 0.01$ & $0.151 \pm 0.03$ \\
\hline Uninoculated (control) & $0.352 \pm 0.03$ & $0.061 \pm 0.01$ & $0.215 \pm 0.05$ \\
\hline P. fluorescens single (S) & $0.717 \pm 0.07$ & $0.152 \pm 0.01$ & $1.096 \pm 0.22$ \\
\hline A. chroococcum single (S) & $0.301 \pm 0.03$ & $0.078 \pm 0.01$ & $0.237 \pm 0.05$ \\
\hline $\begin{array}{l}\text { P. fluorescens }+ \\
\text { A. chroococcum (Mixed). }\end{array}$ & \multicolumn{5}{|l|}{} \\
\hline Unsterilized soil \\
\hline Uninoculated (control) & $0.363 \pm 0.04$ & $0.065 \pm 0.01$ & $0.236 \pm 0.05$ \\
\hline P. fluorescens single (S) & $0.409 \pm 0.04$ & $0.077 \pm 0.01$ & $0.315 \pm 0.07$ \\
\hline A. chroococcum single (S) & $0.594 \pm 0.06$ & $0.140 \pm 0.01$ & $0.835 \pm 0.17$ \\
\hline $\begin{array}{l}\text { P. fluorescens }+ \\
\text { A. chroococcum (Mixed). }\end{array}$ & $0.377 \pm 0.04$ & $0.099 \pm 0.01$ & $0.376 \pm 0.07$ \\
\hline LSD 0.05 & 0.075 & 0.015 & 0.1599 \\
\hline LSD 0.01 & 0.102 & 0.021 & 0.2167 \\
\hline
\end{tabular}

Values are the mean of 4 replicates; \pm shows standard deviation

Table.3 Wheat dry weight, N\% and N-content of wheat as affected by single and mixed inoculations with Azospirillum lipoferum and P. fluorescens

\begin{tabular}{|c|c|c|c|}
\hline Inoculation Treatments & $\begin{array}{ll}\begin{array}{l}\text { Dry } \\
\text { (g/plant) }\end{array} & \text { weight } \\
\end{array}$ & $\begin{array}{l}\text { Shoot } \\
(\mathrm{N} \%)\end{array}$ & $\begin{array}{ll}\mathrm{N} & \text { content } \\
\mathrm{mg} / \text { plant } & \\
\end{array}$ \\
\hline \multicolumn{4}{|l|}{ Sterilized soil } \\
\hline Uninoculated (control) & $0.290 \pm 0.03$ & $0.052 \pm 0.01$ & $0.151 \pm 0.03$ \\
\hline P. fluorescens single (S) & $0.338 \pm 0.03$ & $0.061 \pm 0.01$ & $0.205 \pm 0.04$ \\
\hline A. lipoferum single (S) & $0.752 \pm 0.08$ & $0.198 \pm 0.02$ & $1.500 \pm 0.3$ \\
\hline P. fluorescens + Azospirillum (Mixed). & $0.336 \pm 0.03$ & $0.063 \pm 0.01$ & $0.212 \pm 0.04$ \\
\hline \multicolumn{4}{|l|}{ Unsterilized soil } \\
\hline Uninoculated (control) & $0.363 \pm 0.04$ & $0.065 \pm 0.01$ & $0.237 \pm 0.05$ \\
\hline P. fluorescens single (S) & $0.374 \pm 0.04$ & $0.067 \pm 0.01$ & $0.253 \pm 0.05$ \\
\hline A. lipoferum single (S) & $0.594 \pm 0.06$ & $0.156 \pm 0.02$ & $0.934 \pm 0.19$ \\
\hline P. fluorescens + Azospirillum (Mixed). & $0.419 \pm 0.04$ & $0.075 \pm 0.01$ & $0.315 \pm 0.06$ \\
\hline LSD 0.05 & 0.075 & 0.015 & 0.192 \\
\hline LSD 0.05 & 0.102 & 0.020 & 0.260 \\
\hline
\end{tabular}

Values are the mean of 4 replicates; \pm shows standard deviation 
Photo.1 Antagonistic effect of Pseudomonas fluorescens against Fuasrium sp. on PDA medium (a) comparing with control (b).

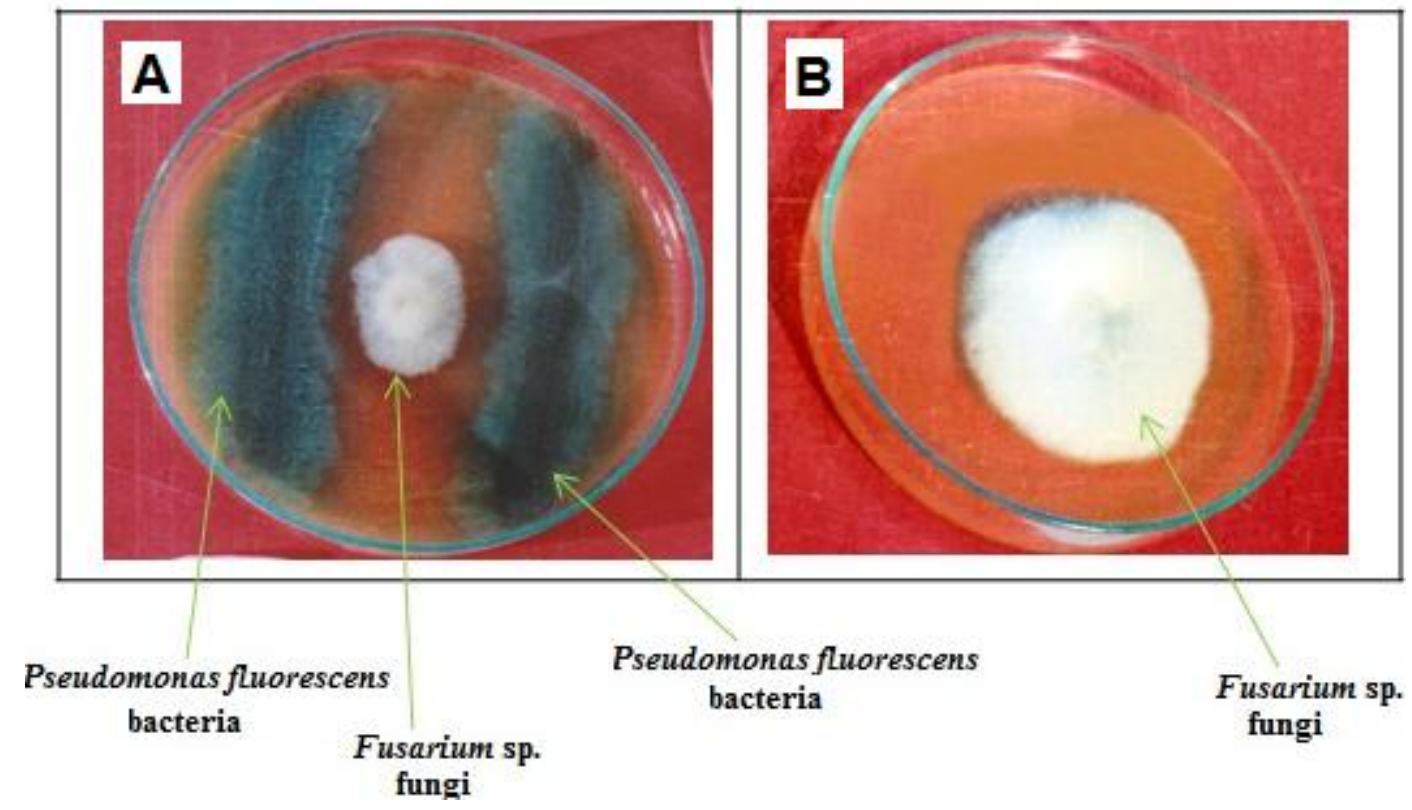

It is obvious that, Cleary, this interaction that can take place in the rhizosphere between biocontrol agents and introduced or indigenous microorganisms need to explored in depth by more studies and researches to point out present and possible future trends in inoculants technology and they need be taken into account when developing bioinoculants for crops to select the compatible organisms before recommending any mixed biofertilizer inoculants and to develop method and time of application.

In conclusion, these results indicate that, $P$. fluorescens as a biological control bacteria able to interfere with the performance of the other rhizosphere microbial like nitrogen fixers bacteria and interacted negatively. In this study the negative interaction effect was happened between biological control $P$. fluorescens and both of $A$. chroococcum or with $A$. lipoferum and influenced negatively their rhizosphere population as well as their $\mathrm{N}$-fixing. On the other hands, because knowledge of rhizosphere bacterial interaction under field conditions is lacking; so we suggested that a compatibility test has to be done before recommending any multi biofertilizer inoculants and more researches under field conditions need to investigate the influence of biocontrol activity of bacterial inoculants and their effects on the indroduce or indigenous other microorganisms.

\section{References}

Abdel-Malek, Y. and Ishac, Y.Z. 1968. Evaluation of methods used in counting Azotobacter, J. Appl. Bact., 31, pp. 269-27.

Abo-Baker, A.A. 2003. Studies on mixed and single microbial inoculations of cultivated plants for improvement of growth and yield. ph.D. Thesis, Fac. Agric. Assiut Univ.

Abo-Baker, A.A. 2011. In vitro, studies on the interaction of Pseudomonas fluorecens and certain tested microorganisms. Annals of Agriculture Science, Moshtohor, Especial Issue Volume (I): 1-6.

Alexander, M. 1965. Most Probable Number 
Method for Microbial Populations. In: Black Methods of Soil Analysis, Page, A.L., R.H. Miller and D.R. Keeney (Ed.. American Society, USA.

Anwar-ul-Haq, M., Anwar, S.A., Shahid, M., Javed, N., Khan, S.A., Mehamood, K. 2011. Management of root knot nematode Meloidogyne incognita by plant growth-promoting rhizobacteria on tomato. Pak. J. Zool., 43: 10271031.

Beever, R.E., and Bollard, E.G. 1970. The nature of the stimulation of fungal growth by potato extract. J. Gen. Microbiol., 60: 273-279.

Berendsen, R.L., Pieterse, C.M. J., Bakker, P.A.H.M. 2012. The rhizosphere microbiome and plant health. Trends Plant Sci., 17 478-486.

Combes-Meynet, E., Pothier, J. F., MoenneLoccoz, Y., Prigent-Combaret, C. 2011. The Pseudomonas secondary metabolite 2,4-diacetylphloroglucinol is a signal inducing rhizoplane expression of Azospirillum genes involved in plant-growth promotion. Mol. Plant Microbe Interact., 24 271284.

Couillerot, O., Prigent-Combaret, C., Caballero-Mellado, J. \& Moe" nneLoccoz, Y. 2009. Pseudomonas fluorescence and closely related fluorescent pseudomonads as biocontrol agents of soil-borne phytopathogens. Lett. Appl. Microbiol., 48, 505-512.

Dennis, C. and Webster, J. 1971. Antagonistic properties of species groups of Trichoderma III hyphal interaction. Trans. Br. Mycol. Soc., 57: 363-369.

Dobereiner, J., I.E. Marriel, and M. nery. 1976. Ecological distribution of Spirillum lipoferum Beijerinck. Can. J. Microbiol., 22: 1464 - 1473.

Gotz, M., Gomes, N.C.M., Dratwinski, A.,
Costa, R., Berg, G., Peixoto, R., Mendonça-Hagler, L., and Smalla, K. 2006. Survival of $g f p$-tagged antagonistic bacteria in the rhizosphere of tomato plants and their effects on the indigenous bacterial community. FEMS Microbiol Ecol., 56, 207-218.

Imam, M.K., Farida H. Badawy and ElHudairy, A. 1977. Response of tomato and two other vegetable crops to inoculation with Azotobacter. Libyan J. Agric., 6: 158-167.

Keel, C., wirthner, Ph., Oberhansli, Th., Voisard, C., Burger, U., Haas, D., and Defago, G. 1990. Pseudomonas as antagonists of plant pathogen in rhizosphere: Role of antibiotic 2,4diacetyl-phloroglucinol in the suppression of black root rot of tobacco. Symbiosis, 9: 327-341.

King, E.O., Ward, M.K. and Raney, D.E. 1954. Two simple media for the demonstration of pyocyanin and fluorescin. J. Lab. Clin. Med., 44, 301307.

Lemanceau, P., Bakker, P. A. H. M., De Kogel, W. J., Alabouvette, C. \& Schippers, B. 1992. Effect of pseudobactin 358 production by Pseudomonas putida WCS358 on suppression of fusarium wilt of carnations by nonpathogenic Fusarium oxysporum Fo47. Appl Environ Microbiol 58, 2978-2982.

Nicodème, M., Grill, J.P, Humbert, G., and Gaillard, J.L. 2005. Extracellular protease activity of different Pseudomonas strains: dependence of proteolytic activity on culture conditions. J. Appl. Microbiol., 99, 641-648.

Olivier, C., Emeline, C., Joe“ 1 F., Floriant, B., Elita, C., Marie, A., Rene,R., Gilles, C., Yvan, M., and Claire, P. 2011. The role of the antimicrobial 
compound 2,4-diacetylphloroglucinol in the impact of biocontrol Pseudomonas fluorescens F113 on Azospirillum brasilense phytostimulators. Microbiol., 157, 1694-1705.

Parke, J.L. 1990. Root colonization by introduced bacteria: A Review. The second international workshop on plant growth promoting rhizobacteria. Switzerland, October, 1990. Proc. Book. pp. 293-297.

Prieto, P., Schiliro, E., MaldonadoGonzalez, M.M., Valderrama, R., Barroso-Albarracin, J.B., MercadoBlanco, J. 2011. Root hairs play a key role in the endophytic colonization of olive roots by Pseudomonas spp. with biocontrol activity. Microb. Ecol., 62: 435-445.

Raaijmakers, J.M., Paulitz, T.C., Steinberg, C., Alabouvette, C. \& Moe" nneLoccoz, Y. 2009. The rhizosphere: a playground and battlefield for soil borne pathogens and beneficial microorganisms. Plant Soil, 321; 341361.

Raaijmakers, J.M., Vlami, M., de Souza, J.T. 2002. Antibiotic production by bacterial biocontrol agents. Anton van Leeuwenhook, 81: 537-547.

Russell, O.F. 1994. MSTAT-C v.2.1 (A computer based data analysis software. Department of Crop and Soil Science, Michigan State University, U.S.A.

Sorensen, J., E. Linda, Jensen and $\mathrm{O}$. Nybroe. 2001. Soil and rhizosphere as habitats for Pseudomonas inoculants: New knowledge on distribution, activity and physiological state derived from micro-scale and single cell studies. Plant and Soil, 232: 97108.

Thomashow, L.S, and Weller, D.M. 1995. Current concepts in the use of introduced bacteria for biological disease control: mechanisms and antifungal metabolites. In: Stacey, G.; Keen, N. eds. Plant-Microbes Interactions. Chapman \& Hall Publ., Nova York, v.1, p.187-235.

Zehra, S., Ahlawat, V.P., and Sehrawat, S.K. 2015. A Study on Compatibility of different Biofertilizers for Nutrient Management in Gladiolus. $J$. Agroecol. Natural Res. Manage, 2(4): 314-316.

\section{How to cite this article:}

Abo-baker Abd-Elmoniem Abo-baker Basha and Rafat Khalaphallah. 2017. The Biological Control Bacteria Pseudomonas fluorescens Inhibits Free Nitrogen Fixing Bacteria in the Rhizosphere. Int.J.Curr.Microbiol.App.Sci. 6(1): 223-231. doi: http://dx.doi.org/10.20546/ijcmas.2017.601.027 